\title{
Thermobarometry of peridotitic Cr-diopside from the Merlin kimberlites, Northern Territory, Australia - nature of the upper mantle beneath the Proterozoic North Australian craton
}

\author{
Taylor, W.R. ${ }^{1}$, Reddicliffe, T.H. ${ }^{2}$, and Jakimowicz, J. ${ }^{2}$
}

${ }^{1}$ R.S.E.S., Australian National University, Canberra, A.C.T. 0200, Australia

${ }^{2}$ Ashton Mining Ltd, P.O. Box 1068, Cloverdale, W.A. 6985, Australia

In order to investigate the thermal state of the upper mantle beneath the Gulf of Carpentaria region of the North Australian craton, the Cr-diopside thermobarometer of Taylor and Nimis (1998) has been applied to a suite of Cr-diopside xenocrysts from two kimberlite pipes in the diamondifeous Merlin field, Northern Territory (Lee et al., 1996). The Gulf of Carpentaria region has been the focus of diamond exploration activity over a number of years. The prospectivity of the region has been enhanced by recent seismic tomography studies (SKIPPY project; B. Kennett, pers. comm.), which indicate the presence of thick mantle lithosphere (up to ca.200km thickness), and heat flow studies which indicate the presence of zones of anomalously cool lithosphere. Both these features are similar to those reported in old, Archaean cratons in which diamondiferous kimberlites are well known. However, the North Australian craton is of Palaeoproterozoic age and was stabilized at ca. $1.8 \mathrm{Ga}$ following the Barramundi orogeny. There is little direct knowledge of the thermal regime in the mantle lithosphere beneath the Australian Proterozoic cratons largely because of the rarity of well preserved mantle xenoliths. The new technique of $\mathrm{Cr}$-diopside thermobarometry (Taylor and Nimis, 1998) is able to provide accurate P-T information from garnet lherzolite-derived Crdiopside using single grains from heavy mineral concentrate samples.

The Merlin field comprises 11 pipes of early Devonian age which intrude Palaeoproterozoic basement and younger cover sequences of the North Australian craton. All the pipes are diamondiferous with grades ranging up to $\sim 100 \mathrm{ct} / 100 \mathrm{t}$. Heavy mineral concentrates from the pipes are dominated by $\mathrm{Cr}$-spinel but small amounts of calcic and subcalcic $\mathrm{Cr}$-pyrope and $\mathrm{Cr}$ diopside have been recovered indicating sampling of deep mantle material of dunitic-toharburgitic and lherzolitic composition. For this study, carefully calibrated EDS microprobe methods were used to analyse $\sim 60 \mathrm{Cr}$-diopside grains picked from concentrates from the Kay pipe; a few grains were included from the adjacent Gareth pipe. Both pipes are located in the northwest part of the Merlin field.

Compositionally, the majority ( $>98 \%$ ) of the $\mathrm{Cr}$-diopsides fall within the garnet peridotite field as defined by Ramsay (1992) on the basis of $\mathrm{Cr}_{2} \mathrm{O}_{3}-\mathrm{Al}_{2} \mathrm{O}_{3}$ discrimination (Fig.1). Of those grains $\sim 15 \%$ have very high $\mathrm{CaO}$ contents ( $>23 \mathrm{wt} \%$; Fig. 2 ) and are probably of garnet wehrlite paragenesis. The remaining grains (mg\# 90-95) are consistent with a garnet lherzolite origin and are suitable for thermobarometry. Of this set, a small proportion of grains were found to be compositionally distinct with low $\mathrm{Al}_{2} \mathrm{O}_{3}(<0.7 \mathrm{wt} \%)$ and low $\mathrm{Na}_{2} \mathrm{O}(<1.5 \mathrm{wt} \%)$ contents. The low-Al diopside in some cases rims or is intergrown with $\mathrm{Cr}$-diopside of normal composition. One unusual grain has $>5 \mathrm{wt} \% \mathrm{Cr}_{2} \mathrm{O}_{3}$ and is rich in kosmochlor component. About one half of the $\mathrm{Cr}$-diopsides have measurable $\mathrm{K}_{2} \mathrm{O}$ contents up to $0.2 \mathrm{wt} \%$.

Results of the application of the Taylor and Nimis (1998) thermobarometer are shown in Fig.3. The data indicates that the Merlin kimberlites have extensively sampled the upper mantlewith most of the $\mathrm{Cr}$-diopside grains being derived from the diamond stability field at $\sim 40-60 \mathrm{kbar}$ pressure (130-200 km depth). The low-Al diopside is mostly derived from pressures near 45 kbar. The highest calculated pressure is $70 \mathrm{kbar}$. The P-T array indicates surprisingly cool conditions for the mantle beneath Merlin in the Devonian. Conditions were equivalent to a conductive geotherm of $\approx 38 \mathrm{~mW} / \mathrm{m}^{2}$ which is similar to that beneath old Archaean cratonic areas such as the Kaapvaal craton. The cool conditions at Merlin seem remarkable for Proterozoic mantle and compare with the higher geotherm of $\approx 42 \mathrm{~mW} / \mathrm{m}^{2}$ calculated for the mantle lithosphere beneath the Argyle lamproite pipe in the western part of the craton (Taylor and Nimis, 1998). The results suggest that some Proterozoic terranes can develop the thick, cool mantle roots generally considered to be restricted to the Archaean. One possibility is that 
the cool Merlin lithosphere represents a remnant of an Archaean mantle root above which there is no presently exposed (or perhaps preserved) Archaean crust.

Fig.1

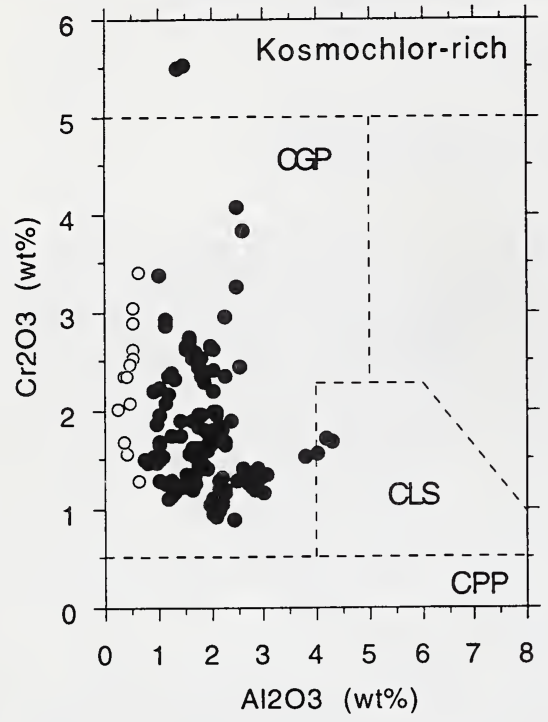

- Cr-diopside o Low-Al diopside
Fig.2

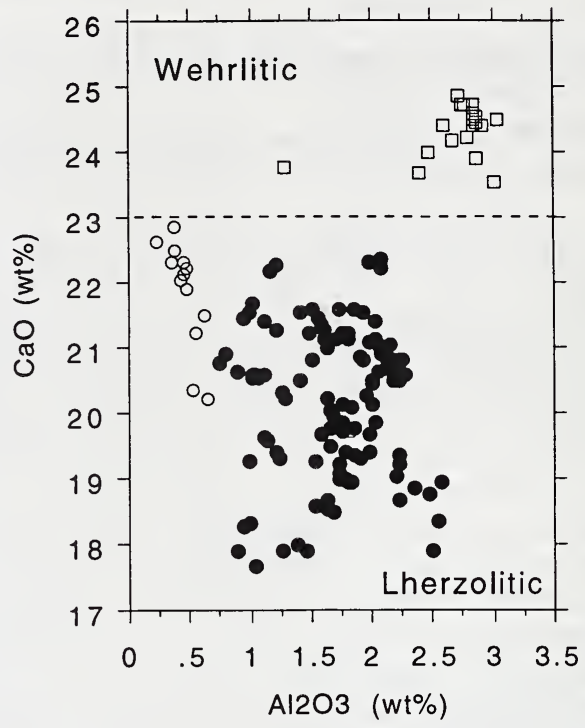

口 Wehrlitic Cr-diopside (Fig.2)

Figures 1 and 2:

Discriminant diagrams used to classify mantle-derived clinopyroxene. Only those derived from garnet Iherzolite can yield meaningful P,T estimates by the Taylor and Nimis (1998) method. Figure 1 is after Ramsay (1992); CGP = garnet peridotite field, $C L S=$ spinel Iherzolite field, CPP = pyroxenite, eclogite and cognate field. Figure 2 is used to distinguish $\mathrm{Cr}$-diopside from wehrlitic and Iherzolitic sources.

Fig. 3

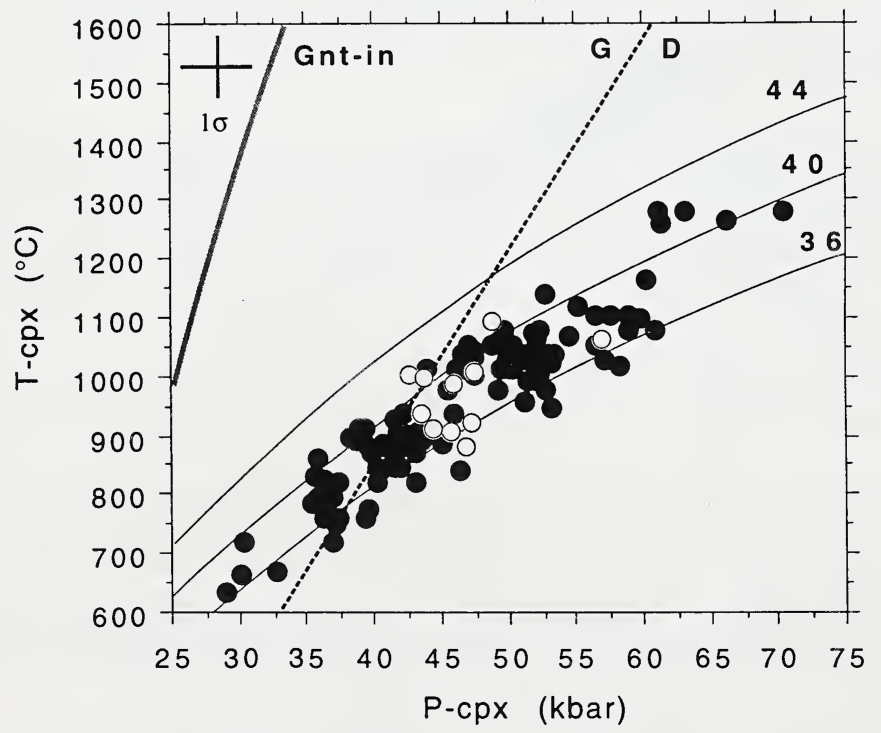

Figure 3:

P-T array calculated for the Merlin Cr-diopsides. Sample conductive geotherms (labelled 44,40 and 36 $\mathrm{mW} / \mathrm{m} 2$ ) are shown. $\mathrm{G}=$ graphite; $D=$ diamond. Garnet-in boundary is for depleted peridotite. The lithosphere sampled by the Merlin kimberlites is unusually cool and similar to that found beneath Archaean cratons. 


\section{References}

Lee, D.C., Reddicliffe, T.H., Scott Smith, B.H., Taylor, W.R., and Ward, L.M., 1997, The Merlin kimberlites, Northern Territory, Australia. Russ. Geol. Geophys., 6th International Kimberlite Conference Proceedings, Vol. 1, 38, p. 78-82.

Ramsay, R.R., 1992, Geochemistry of Diamond Indicator Minerals, Unpubl. PhD thesis, University of Western Australia.

Taylor, W.R., and Nimis, P., 1998, A single-pyroxene thermobarometer for lherzolitic Crdiopside and its application in diamond exploration, this volume. 